GEAP-5035

AEC RESEARCH AND DEVELOPMENT REPORT AUGUST 1966

\title{
USE OF NEUTRON FILTERS FOR FAST REACTOR FUEL IRRADIATIONS IN A THERMAL REACTOR CORE
}

\author{
L. E. WILKINSON \\ R. P. MORISSETTE \\ J. H. FIELD \\ U.S. ATOMIC ENERGY COMMISSION \\ CONTRACT AT(04-3)=189 \\ PROJECT AGREEMENT 540
}

NUCLEAR ENERGY DIVISION GENERAL (g: ELECTRIC SAN JOSE, CALIFORNIA 


\section{DISCLAIMER}

This report was prepared as an account of work sponsored by an agency of the United States Government. Neither the United States Government nor any agency Thereof, nor any of their employees, makes any warranty, express or implied, or assumes any legal liability or responsibility for the accuracy, completeness, or usefulness of any information, apparatus, product, or process disclosed, or represents that its use would not infringe privately owned rights. Reference herein to any specific commercial product, process, or service by trade name, trademark, manufacturer, or otherwise does not necessarily constitute or imply its endorsement, recommendation, or favoring by the United States Government or any agency thereof. The views and opinions of authors expressed herein do not necessarily state or reflect those of the United States Government or any agency thereof. 


\section{DISCLAIMER}

Portions of this document may be illegible in electronic image products. Images are produced from the best available original document. 


\section{LEGAL NUIICE}

This report was prepared as an account of Government sponsored work. Neither the United tates, nor the Commission, nor any person acting on behalf of the Commission:

A. Makes any warranty or representation, expressed or Implled, with respect to the accuracy, completeness, or usefulness of the information contained in this report, or that the use of any information, apparatus, method, or process disclosed in this report may not infringe privateiy owned rights; or

B. Assumes any liabilties with respect to the use of, or for damages resulting from the use of any information, apparatus, method, or process disclosed in this report.

As used in the above, "person acting on behalf of the Commission" includes any employee or contractor of the Commission, or employee of such contractor, to the extent that such employee or contractor of the Commission, or employee of such contractor prepares, disseminates, or provides access to, any information pursuant to his employment or contract with the Commission, or his employment with such contractor.
AEC Research and Development Report August 1966

COSAI PDITHS

USE OF NEUTRON FILTERS FOR FAST REACTOR FUEL IRRADIATIONS IN A THERMAL REACTOR CORE

L. E. Wilkinson

R. P. Morissette

J. H. Field

Approved:

\section{S.m. Woot}

K. M. Horst Development Project Engineer SEFOR Preoperational $\mathrm{R}$ and $\mathrm{D}$

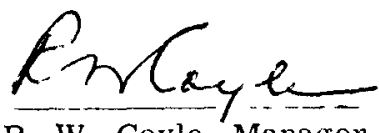

R. W. Coyle, Manager Program Management

\subsection{Splask \\ E. L. Zebroski, Manager Sodium Reactor Technology Advanced Products Operation}

U. S. Atomic Energy Commission Contract AT(04-3)-189

Project Agreement 540

Printed in U.S.A. Available from the Clearing House for Federal Scientific and Technical Information National Bureau of Standards, U.S. Department of Commerce Springfield, Virginia Price: $\$ 1.00$ per copy 


\section{LEGAL NOTICE}

This report was prepared as an account of Government sponsored work. Neither the United States, nor the Commission, nor any person acting on behalf of the Commission:

A. Makes any warranty or representation, expressed or implied, with respect to the accuracy, completeness, or usefulness of the information contained in this report, or that the use of any information, apparatus, method, or process disclosed in this report may not infringe privately owned rights; or

B. Assumes any liabilities with respect to the use of, or for damages resulting from the use of any information, apparatus, method. or process disclosed in this report.

As used in the above, "person acting on behalf of the Commission" includes any employee or contractor of the Commission, or employee of such contractor, to the extent that such employee or contractor of the Commission, or employee of such contractor prepares, disseminates, or provides access to, any information pursuant to his employment or contract with the Commission, or his employment with such contractor. 
CONTENTS

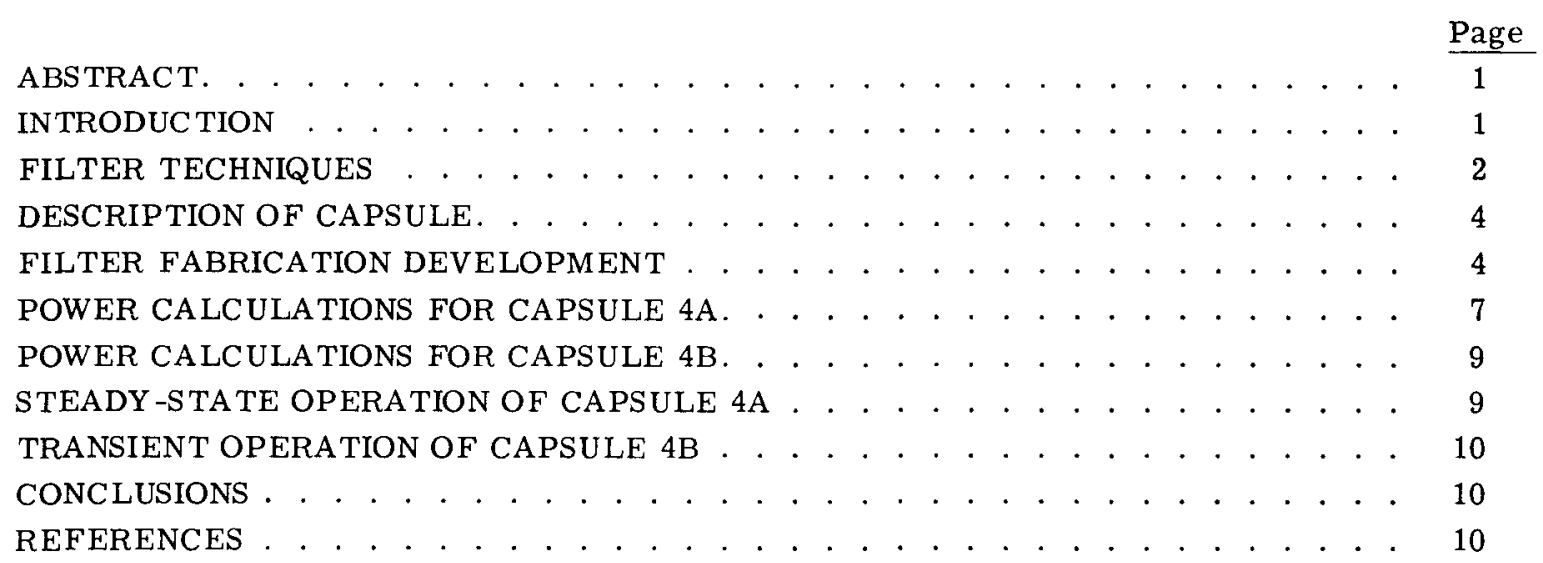




\title{
USE OF NEUTRON FILTERS FOR FAST REACTOR FUEL IRRADIATIONS IN A THERMAL REACTOR CORE
}

\author{
L. E. Wilkinson * \\ R. P. Morissette * \\ J. H. Field +
}

\begin{abstract}
The use of filters is discussed for cases in which it is desirable to harden the spectrum of the incident neutrons on specimens of high cross section. It is shown that significant improvements can be made in the surface-to-center (and peak-to-average) power production ratios. This technique results in an improved temperature distribution in the fuel specimen that is more prototypical of the temperature profiles expected in the fast reactor fuels.
\end{abstract}

A demonstration of this technique is discussed in which an 0.875 -inch diameter mixed oxide fuel containing $17 \% \mathrm{PuO}_{2}$ produced $18 \mathrm{~kW} / \mathrm{ft}$ in a thermal reactor core after elimination of essentially all thermal neutrons.

\section{INTRODUCTION}

The Southwest Experimental Fast Oxide Reactor (SEFOR) is a 20-MW(t) fast spectrum reactor fueled with $\mathrm{PuO}_{2}-\mathrm{UO}_{2}$ and cooled with sodium. SEFOR will have characteristics similar to the large, soft spectrum, fast breeder reactors fueled with mixed $\mathrm{PuO}_{2}-\mathrm{UO}_{2}$. Economic studies of these large power reactors indicate the potential for producing low cost power. SEFOR will be used to obtain physics and engineering data at fuel compositions, temperatures, and crystalline state characteristic of power reactor operating conditions. SEFOR is particularly designed for the systematic determination of the Doppler coefficient of reactivity at temperatures up to the vicinity of fuel melting.

The SEFOR Project consists of two major parts: the design and construction of the reactor and a related research and development program. Funds for the design and construction of the facility are being provided by the Southwest Atomic Energy Associates ( a group of seventeen investor-owned utility companies located in the South and Southwest part of the United States), and the Karlsruhe Laboratory of West Germany, EURATOM, and the General Electric Company.

The United States Atomic Energy Commission is supporting the research and development program. The Research and Development Program consists of two phases:

Phase I - Pre-Operational Research and Development

Phase II - Post-Construction Research and Development (the program)

* Irradiation Processing Operation

+ Advanced Products Operation

$\$$ Presented at the International Symposium on Developments in Irradiation Capsule Technology Castlewood Country Club, Pleasanton, California, May $3-5,1966$. 
The work described in this report was performed during Phase I of the Research and Development Program under Task 3.0, Fuel Development.

The purpose of this task was to gain experimental information, through transient and nontransient fuel testing, to guide the design of the fuel and to establish operation Iimits for SEFOR. Large diameter $\left(0.875\right.$ - Inch) mixed oxide fuel rods approaching $20 \% \mathrm{PuO}_{2}$ were planned for SEFOR and it was very desirable to use similar fuel pins in the fuel testing program.

At the time this program was carried out, most irradiation testing (including all transient testing) was restricted to thermal reactors because of the lack of fast reactor irradiation facilities. This fact, coupled with the need for tests at prototypical SEFOR size and enrichment, gave rise to an investigation of thermal neutron flux filters as a means to reduce the severe self-shielding and achieve a more nearly typical radial power and temperature profile.

Two capsules with cadmium flux filters which have been used in the SEFOR program to remove the thermal neutron component from the flux environment in a thermal test reactor core are described.* By removing the thermal flux component, the self-shielding in a $17 \%$ enriched specimen was estimated to be equivalent to a $5 \%$ enriched specimen in an unfiltered flux. Even though $5 \%$ fuel enrichment in a thermal spectrum does cause more self-shielding than prototypical fuel in a fast reactor, the steady-state temperature profile in the fuel was judged to be an adequate likeness for worthwhle testing

\section{FILTER TECHNIQUES}

The use of neutron filters per se is not new, especially in the field of reactor physics. Cadmium ratios have been used for many years to define a ratio of thermal-to-fast neutrons. This is done simply by taking the ratio of activation of two dosimeter wires or folls (one cadmium coated and one uncoated) exposed to a normal thermal flux spectrum. Filters have also been used in process flow channels to harden the neutron spectrum to decrease depression factors in large experimental ass emblies.

In the SEFOR program, the use of filters in fuel irradiation capsules was desired for both steady-state experiments in a thermal test reactor (such as GETR) and for transient irradiations in TREAT. For the steady-state capsule (4A), a simple cadmium sleeve was used to simplify calculation and fabrication techniques. The calculated decrease in the self-shielding is shown in Figure 1.

* A description of the fuel irradiation experiments conducted under the SEFOR project will be included in a forthcoming report. 


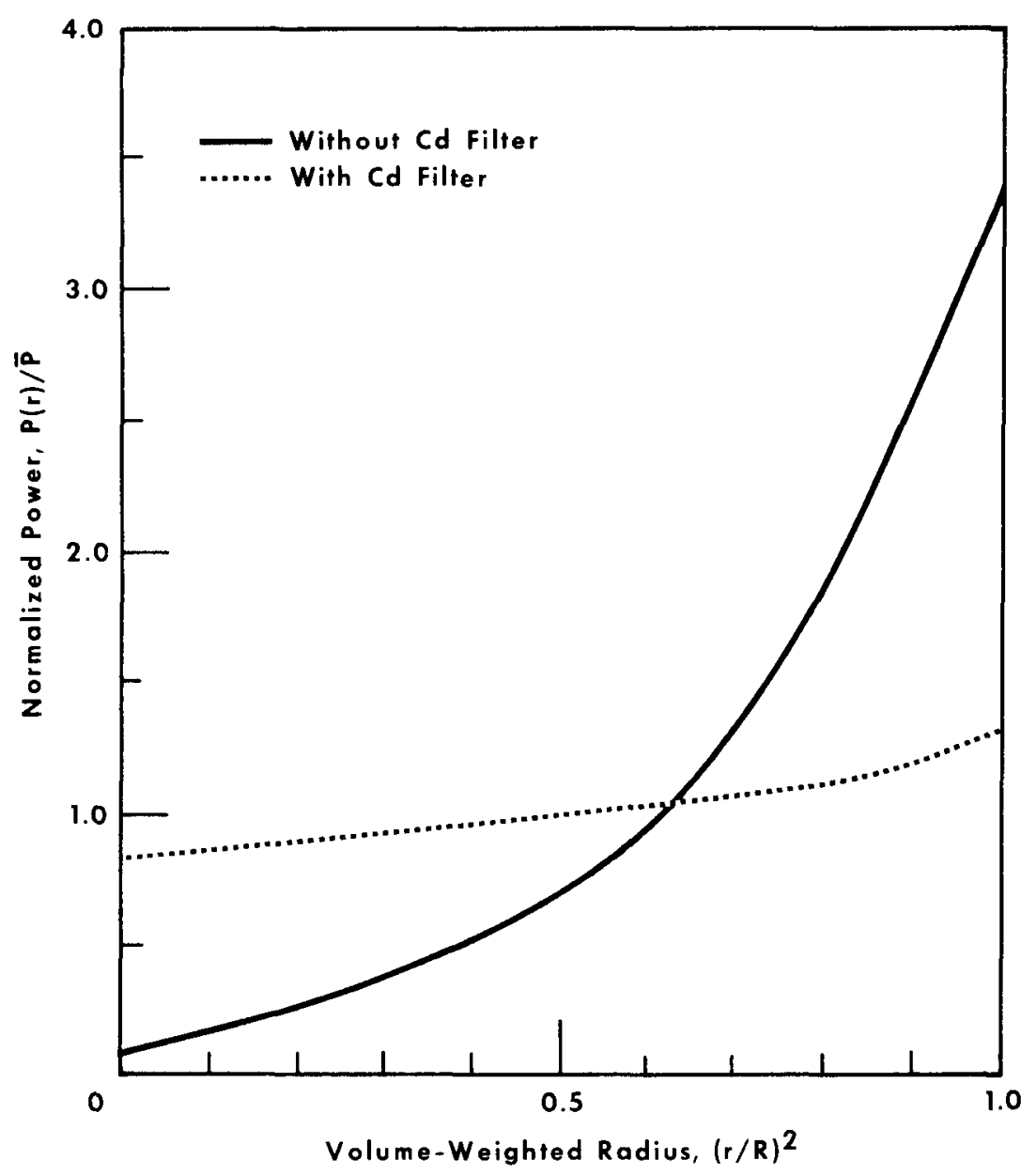

FIGURE I CALCULATED RADIAL FISSION POWER DISTRIBUTION IN SEFOR SPECIMEN 4A CONTAINING $17 \% \mathrm{PUO}_{2}-83 \% \mathrm{UO}_{2}$ 
In the transient capsule (4B) several alternatives were considered, including (a) an external cadmium layer and an aluminum heat sink (to avoid rethermalızing the flux with the normal beryllium heat sink) and (b) replacement of the beryllium heat sink with nickel. The cadmium filter was gain selected based on the comparison with a $5 \%$ enriched unfiltered case (Figure 2). The $5 \%$ enrichment was used as a base case since this enrichment had been used on other SEFOR experiments in TREAT.

\section{DESCRIPTION OF CAPSULE}

The steady-state irradiation capsule, 4A, (Figure 3) is 1-3/4 inches in diameter and contained a stack of $\mathrm{UO}_{2}-17^{\circ} \mathrm{PuO}_{2}$ pellets of 0.875 -inch diameter. The fuel was clad in Type-316 stainless steel and contained natural $\mathrm{UO}_{2}$ insulators at both ends. A telescoping extensiometer was placed at the top of the fuel column to record the differential expansion of the fuel during full power conditions. Since the fuel column was expected to expand up to $12 \mathrm{inch}$, the cadmium sleeve surrounding the fuel extended 1-1 2 inches beyond the top of the fuel (at room temperature) and $1 \mathrm{inch}$ below the bottom of the fuel. Thi ee nickel and iron dosimeter wires were clipped inside the flux filter to record the neutron flux

The cadmium sleeve for Capsule 4A was clad with Type-304 stanless steel and served as a primary container outside the fuel specimen. Sodium was used for bonding inside the primary container and $\mathrm{NaK}$ in the secondary container. The fuel specimen was instrumented both internally and externally with tungsten-rhenium and Chromel-Alumel thermocouples, respectively. ChromelAlumel thermocouples were also used inside and outside the cadmium sleeve. The highest temperature Chromel-Alumel thermocouple was used fo, control to assure that the cadmium was operated in-pile below its melting point $(610 \mathrm{~F})$.

For the transient irradiations in TREAT. capsule 4B was designed with an interchangable cadmium filter to provide flexibility at the time of irradiation. This change was in recognition of the inherent uncertanties in the TREAT flux spectrum, and provided for the use of some thermal flux If such become necessary. As assembled, the capsule incorporated a 0.025 -inch thick cadmium layer, but a 0.007 -inch filter was also fabricated. The capsule utılized an aluminum heat sink, was sodium filled and was equipped with a tungsten-rhenium in-fuel thermocouple. ${ }^{(1,2,3)}$

\section{FILTER FABRICATION DEVELOPMENT}

The initial criteria required in the cadmium filter sleeve for SEFOR Capsule $4 \mathrm{~A}$ were no voids and complete bonding Several surface preparations and melting techniques were used before a satisfactory product was obtained. The process described below is the final effort and resulted in generally good bonding on both the inner and outer surfaces of the cadmium with no unbonded areas greater than $1 / 8$ inch diameter. The $1 / 8$-inch small volds were judged satisfactory in view of the thickness of the cadmium $(0.035 \mathrm{nnch})$. The extent of bonding achieved indiated that the cadmium 
GAP -5035

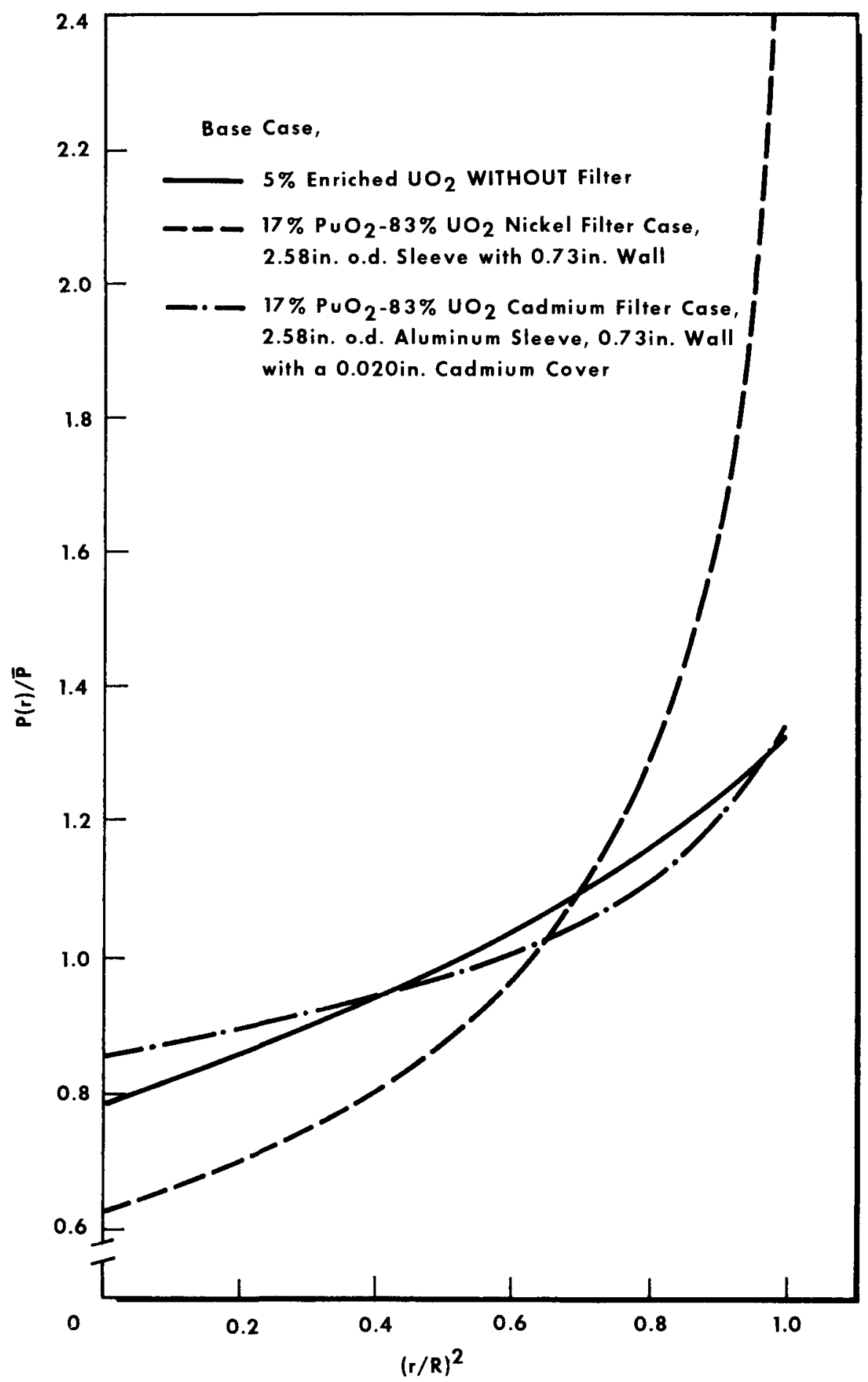

FIGURE 2 RELATIVE FISSION DISTRIBUTION FOR SEFOR AB SPECIMEN IN TREAT

5 
GEAR -5035

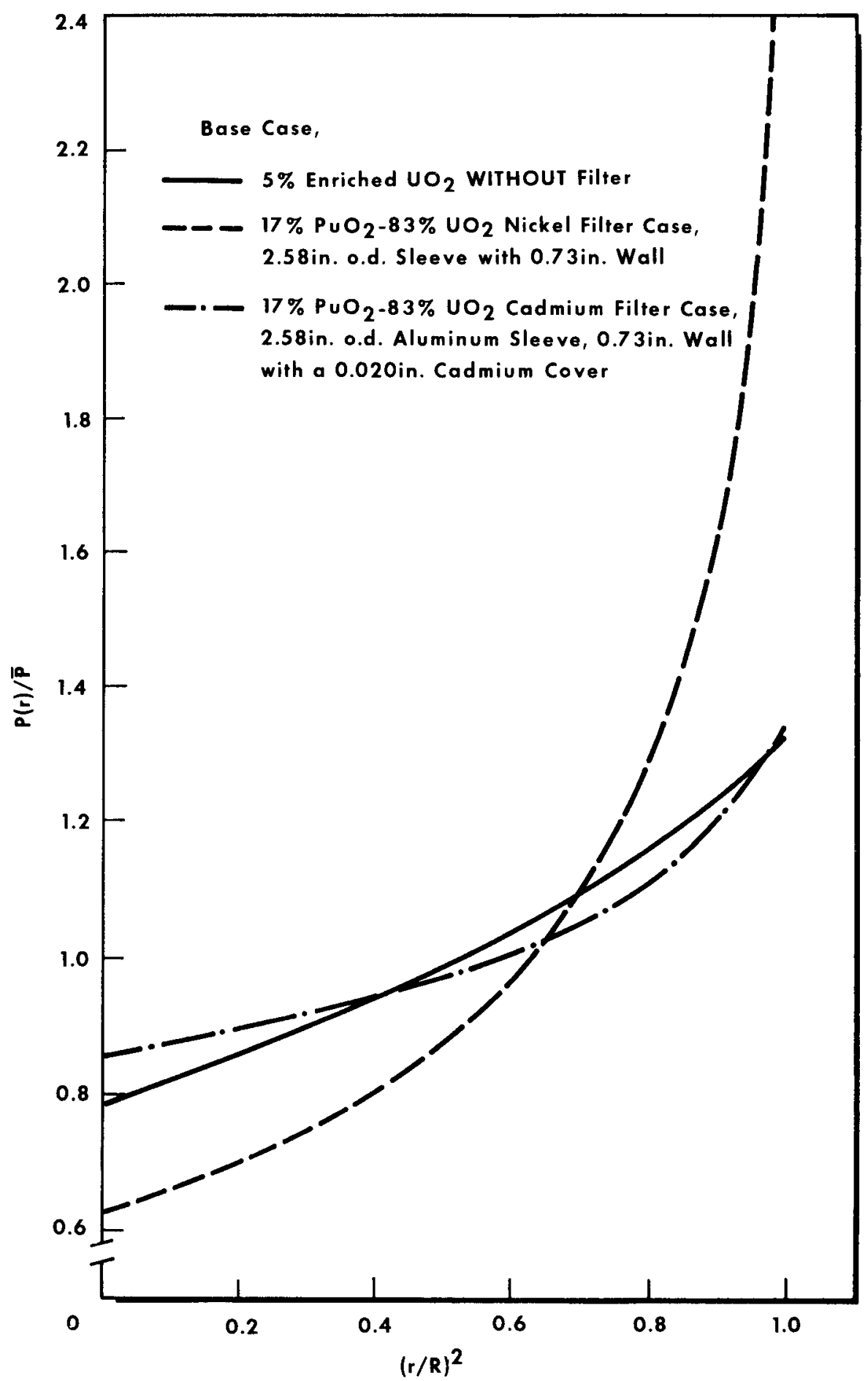

FIGURE 2 RELATIVE FISSION DISTRIBUTION FOR SEFOR AB SPECIMEN IN TREAT

5 


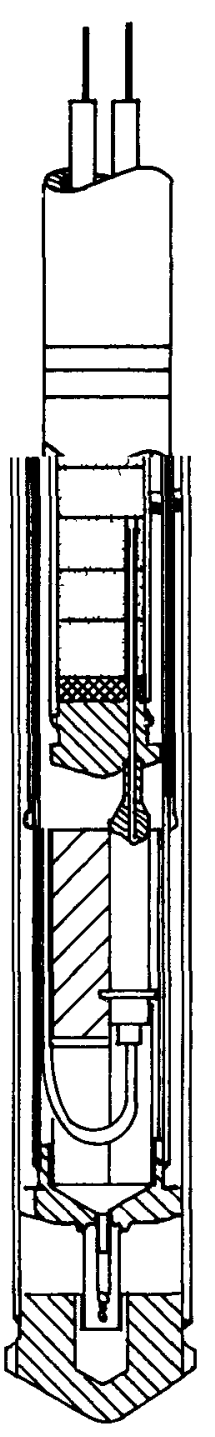


would be in intimate contact with the cladding at operating temperature and, therefore, satisfactory at the heat fluxes considered $\left(\sim 250,000 \mathrm{Btu} / \mathrm{h}-\mathrm{ft}^{2}\right)$.

Before assembly, all surfaces in which cadmium bonding was desired were electroplated with 3 to 4 mils of cadmium. The machined and plated parts were then cleaned and assembled in a flux filter fixture (Figure 4). Among the machined parts was a sheet of cadmium that was rolled to fit into the annulus provided in the stainless steel concentric tubes.

The assembled fixture was placed into a tube furnace and evacuated untıl the furnace reached $600^{\circ} \mathrm{F}$. Above the cadmium melting point, an argon atmosphere was used to suppress the toxic cadmium vapors. The fixture was then heated to a minımum of $800^{\wedge} \mathrm{F}$ and held for 3 to 4 hours. Vacuum and vibration were used intermittently to clear the annulus of any gaseous impurities. The resultant products were $\mathrm{x}$-rayed and examined metallographically (on control specimens) to evaluate voids and bonding. Following inspection approval, the fixture was dissected by removing the fliter portion for its inclusion in the capsule container.

\section{POWER CALCULATIONS FOR CAPSULE 4A}

With the thermal neutron flux component removed from the fuel, other sources of power become predominant. (1) fission from epithermal and fast neutrons, (2) gamma heating, and (3) reaction heating (in the cadmium). The fission cross sections of plutonium for epithermal and fast neutrons are difficult to deal with at best and contributed to the decision to use pure cadmium in the filter instead of a more ideal metallurgical alloy, such as silver-indium-cadmium. Epıthermal resonance cross sections in both silver and indium would have lead to greater uncertainties in the power calculations.

Since in the steady-state capsule, core positions were needed to obtain a high epithermal and fast neutron flux, the gamma heating was high also. In the outer core position of GETR selected for the experiment, the gamma heating effect was calculated to be nearly one-half the fission heating. An estimate of the average power generation rates in the Capsule $4 \mathrm{~A}$ fuel specimen and the flux filter appear below.

\section{INSIDE SPECIMEN}

\section{Heat Source}

Fission - thermal neutrons $(<0.17 \mathrm{eV})$

Fission - epithermal neutrons $(0.17 \mathrm{eV}$ to $0.18 \mathrm{MeV})$

Fission - fast neutrons ( $>0.18 \mathrm{MeV})$

Gamma - in fuel

\section{Total Specimen Power}

\section{OUTSIDE SPECIMEN}

\author{
Specific Power $(\mathrm{W} / \mathrm{gm})$ \\ $<0.01$ \\ 9.9 \\ 1.8 \\ $\frac{5}{16.7}$ \\ (1)
}

Linear Rate $(\mathrm{kW} / \mathrm{ft})$

$-0.1$

11.8

2.2

$\frac{6}{20}$

Gamma - in filter

Reaction - in filter 


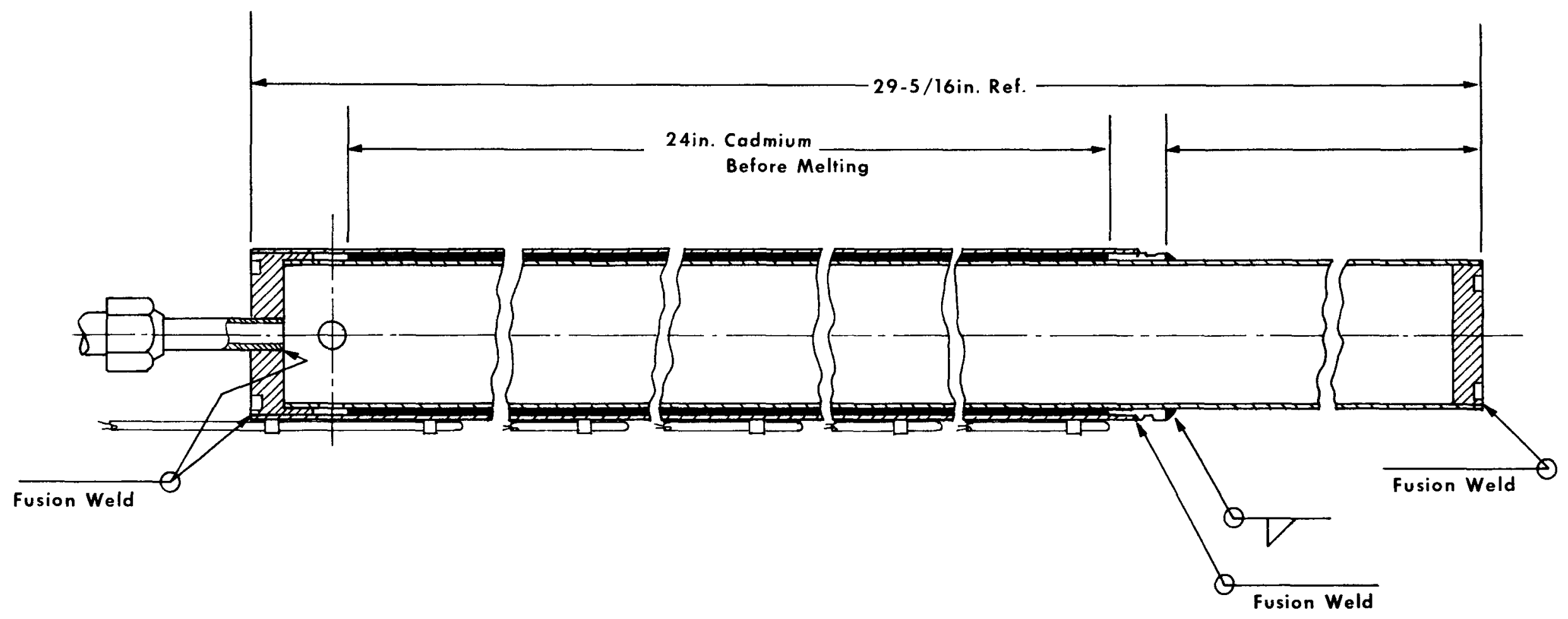

FIGURE 4 FLUX FILTER MOLTING FIXTURE 
Fission heating was calculated for the SEFOR Capsule 4A in the GETR core by using a onedimensional transport theory determination of flux depression, and PDQ, ${ }^{(4)}$ a two-dimensional diffusion theory flux calculation to determine interaction of the capsule with the reactor.

\section{POWER CALCULATIONS FOR CAPSULE 4B}

To calculate the epithermal power depression in the Capsule $4 \mathrm{~B}$, a computer code, REAX, (5) was written. This code subdivides the energy range immediately above thermal into as many as 2000 energy groups and calculates in each energy group, the source, flux, and Doppler-broadened cross sections as a function of radial position in a fuel rod. These calculation have been described in detail by Protsik. ${ }^{(5)}$

The specimen power generation was calculated using PDQ with thermal and epithermal cross sections obtained from THERMOS ${ }^{(6)}$ and REAX. The results are shown below and compared to the $5 \%$ enriched, unfiltered case:

\begin{tabular}{|c|c|c|}
\hline & $\begin{array}{l}\mathrm{UO}_{2} 5 \% \text { Enriched } \\
\text { Without Filter }\end{array}$ & $\begin{array}{c}\mathrm{UO}_{2}-17 \% \mathrm{PuO}_{2} 25 \mathrm{mil} \\
\text { Cadmium Filter }\end{array}$ \\
\hline Fuel Pin (fissions/cc) & $2.663 \times 10^{-5}$ & $1.058 \times 10^{-5}$ \\
\hline TREAT Fissions & & \\
\hline Insulator (fissions $/ \mathrm{cc}$ ) $=$ & $4.015 \times 10^{-6}$ & $0.574 \times 10^{-6}$ \\
\hline TREAT Fissions & & \\
\hline Power Spectrum, \% & & \\
\hline $\begin{array}{l}\text { Fast }(>9.1 \mathrm{keV}) \\
\text { High Epithermal }(55.6 \mathrm{ev} \text { to } 9.1 \mathrm{keV}) \\
\text { Low Epithermal }(0.625 \text { to } 55.6 \mathrm{ev}) \\
\text { Thermal }(<0.625 \mathrm{eV})\end{array}$ & $\begin{array}{r}2.77 \\
4.96 \\
9.24 \\
83.03\end{array}$ & $\begin{array}{l}11.75 \\
28.91 \\
43.49 \\
15.85\end{array}$ \\
\hline
\end{tabular}

\section{STEADY-STATE OPERATION OF CAPSULE 4A}

Capsule 4A was ir radiated in the GETR during Cycles 72 and 73 . The capsule completed 55 days of operation corresponding to a burnup of $\sim 600 \mathrm{MWd} / \mathrm{MT}$. Peak fission power at the lower end of the fuel averaged over the irradiation period, was $13.3 \mathrm{~kW} / \mathrm{ft}$. The corresponding total power (fission + gamma) was $17.9 \mathrm{~kW} / \mathrm{ft}$ which compared well with the desired power of $20 \mathrm{~kW} / \mathrm{ft}$. Calculated average fuel temperature at the peak position was $4000^{\circ} \mathrm{F}$. Both the central fuel thermocouple (at the low power end of the pin) and the mid-radius thermocouple (at the high power end of the pin) indicated temperatures in excess of $3000^{\circ} \mathrm{F}$ early in the irradiation, but became erratic with continued expusure. 


\section{TRANSIENT OPERATION OF CAPSULE 4B}

Capsule $4 B$ was subjected to four filtered flux transients in TREAT. Test data show ed that insufficient fast flux was available in TREAT at maximum power to attain the desired central temperatures. Both thicknesses of cadmium discussed under "Description of Capsule" were used in the tests. Extrapolated data from a low power transient with the 0.025 inch thickness of cadmium predicted a peak temperature of less than $3500^{\circ} \mathrm{F}$ (versus the $4800^{\circ} \mathrm{F}$ desired) at maximum TREAT power. The 0.007-inch filter was installed, and at maximum TREAT power, a temperature of $3800^{\circ} \mathrm{F}$ was reached, but with a calculated flux depression substantially greater than the base case $\left(5 \%\right.$ enriched $\left.\mathrm{UO}_{2}\right)$ and atypical of SEFOR conditions.

\section{CONCLUSIONS}

Based on the experience with these SEFOR capsules it can be concluded that

1. Power calculations on mixed oxide in a thermal reactor with cadmium as a thermal neutron filter can be performed with reasonable accuracy, where the spectrum is well characterized

2. A thei mal neutron filter with cadmium can be cast in stainless steel without large voids and with some metallurgical bonding

3. Flux filters can be used to improve the testing of fast reactor fuel compositions in thermal test reactors, where there is a substantial fast and epithermal flux component.

\section{REFERENCES}

1. Horst, K M., Ed., Southwest Experimental Fast Oxide Reactor Development Program, 6th Quarterly, August-October, 1965, GEAP-4994, November 1965.

2. Horst, K.M , Ed , Southwest Experımental Fast Oxide Reactor Development Program, 7th Quarterly, November 1965-January 1966, GEAP-5108, February 1966.

3. Horst, K.M., Ed., Southwest Experımental Fast Oxıde Reactor Development Program, 8th Quarterly, February-April 1965, GEAP-5160, May 1966.

4 Cadwell, W. R., "PDQ-4 - A Program for the Solution of the Neutron Diffusion Equations in Two Dimensions for the Philco 2000," WAPD-TM-230, June 1961.

5 Protsik, R., "Epithermal Capture and Fission Distribution in a Fuel Rod - The Computer Code REAX," GEAP-4973, Apr 11966.

6. Honeck, H.C., "THERMOS, A Thermalization Transport Theory Code for Reactor Lattice Calculations," BNL-5826, November 1962. 
Mr. W. H. Brummett, Jr.

Director, Contracts Division

U. S. Atomic Energy Connission

San Francisco Operations Office

2111 Bancroft Way

Berkeley, California 94704

Mr. J. P. Holliday

Reactor Division

U. S. Atomic Energy Commission

San Francisco Operations Office

2111 Bancroft Way

Berkeley, California 94704

Director, Reactor Division

U. S. Atomic Energy Commission

San Francisco Operations Office

2111 Bancroft Way

Berkeley, California 94704

Dr. G. W. Wensch

Chief, Liquid Metal Cooled Reactors Branch

Division of Reactor Development

U. S. Atomic Energy Commission

Washington 25 , D. C.

Dr. J. A. Lieberman

Asst. Director for Nuclear Safety

Division of Reactor Development

U. S. Atomic Energy Commission

Washington 25, D. C.

Manager, USAEC

Chicago Operations Office

9800 South Cass Avenue

Argonne, Illinois

Attn: A. Mravca

Director, Reactor Engineering Division

U. S. Atomic Energy Commission

Chicago Operations Office

9800 South Cass Avenue

Argonne, Illinois

F. W. Thaigott

Associate Director, Idaho Falls Division

Argonne National Laboratory

Box 2528

Idaho Falls, Idaho

Director Argonne National Laboratory

Argonne, Illinois

Attn: S. Lawrowski

W. R. Simmons

Argonne National Laboratory

9800 South Cass Avenue

Argonne, Illinois 
Director

os Alamos Scientific Laboratory

Los Alamos, New Mexico

Dr. John C. Woodhouse

1

1 Guest Lane

Wilmington, Delaware

Senior Representative

3

U. S. Mission to Euratom Communities

c/o U. S. Embassy

Brussels, Belguim

General Directorate

Research and Training

Euratom

51-53 Rue Belliard

Brussels, Belyium

Attn: A. de Stordeur

Mr. C. C. Czeschin, President

1

Arkansas-Missouri Power Company

104 South Fifth Street

Blytheville, Arkansas

Mr. F. H. Coughlin, President

1

Central Louisiana Electric Company, Inc.

415 Main Street

Pineville, Louisiana

Mr. John Stewart, President

111 East 11th Street

Hays, Kansas

Mr. Reeves Ritchie, President

Arkansas Power \& Light Co.

Ninth and Louisiana St.

Little Rock, Arkansas

Mr. J. T. Jones, President

The Empire District Electric Company

602 Joplin Street

Joplin, Missouri

Mr. Harold E. Mortimer

Assistant to Chairman of the Board

Gulf States Utilities Company

P.O.Box 2951

Beaumont, Texas

Mr. G. W. Evans, President

Kansas Gas and Electric Company

201 North Market Street

Wichita, Kanses

Mr. L. F. C. Reichie

Ebasco Services, Inc.

2 Rector Street

New York 6, New York 
Mr. W. O. Turner, Chairman of Board

Louisiana Power \& Light Company

142 Delaronde Street

New Orleans, Louisiana

Mr. R. B. Wilson, President

Mississippi Power \& Light Company

Electric Building

Jackson, Mississippi

Mr. R. C. Green, President

Missouri Public Service Company

10700 East 50 Highway

Kansas City, Missouri

Mr. Ray W. Call, President

Missouri Utilities Company

400 Broadway

Cape Girardeau, Missouri

Mr. L. J. Cucullu, Vice President

New Orleans Public Service Inc.

317 Baronne Street

New Orleans, Louisiana

Mr. D. S. Kennedy, President

Kklahoma Gas and Electric Company

321 North Harvey Street

Oklahoma City. Oklahoma

Mr. B. S. Jeffrey, President

Kansas Power \& Light Co.

808 Kansas Ave.

Topeka, Kansas

Mr. D. J. Tuepker, President

Public Service Company of Oklahoma

600 South Main Street

Tulsa, Oklahoma

Mr. J. Robert Welsh, President

Southwestern Electric Power Company

P.O. Box 1106

Shreveport, Louisiana

Mr. C. F. Edwards, Vice President

Western Power \& Gas Company, Inc.

P.O.Box 170

Great Bend, Kansas

Gesellschaft fur Kernforschung m.b.h.

Projekt Schneller Bruter

75) Karlsruhe, Germany

Postfach 947

Division of Technical Information Extension

U. S. Atomic Energy Commission

P. O. Box 62

Oak Ridge, Tennessee 
Director

Research \& Development Division

U. S. Atomic Energy Commission

Richland Operations Office

P.O. Box 550

Richland, Washington, 99352

Brookhaven National Laboratory

1

Associated Universities, Inc.

Upton, Long Is land, New York 11973

Attn: Dr. C. J. Raseman

Professor W. Haefele

Kernforschungssentrum Karls ruhe

7500 Karlsruhe, Germany

Mr. G. Vendryes

CEN Saclay

Boite Postale 2

Gif-Sur-Yvette (8 et 0), France

Dott. Ing. F. Pierantoni

CNEN

Via Mazzini 2

Bologna, Italy

Mr. J. J. Morabito

Project Manager

Special Projects Branch

Division of Reactor Development and Technology

U. S. Atomic Energy Commission

Washington D. C. 20545

Mr. W. W. Mark

Fuel Fabrication Branch

Division of Reactor Development and Technology

USAEC

Washington, D.C. 20545

Mr. L. E. Ling (Acting Director)

LMFBR Program Affice

Argonne National Laboratory

$9700 \mathrm{~S}$. Cass Avenue

Argonne, Illinois

Power Reactor Development Co.

1911 First Street

Detroit 26, Michigan

Mr. E. R. Astley

Project Manager

FFTF Project

Pacific Northwest Laboratory

Richland, Washington 99352

Mr. J. Crawford

Asst. Dir. for Plant Engineering

DRD \& $T$

USAEC

Washington 25 , D. C. 
Mr. M. Whitman

2

Asst. Director for Reactor Engineering

D \& I

USAEC

Washington 25, D. C.

Mr. J. M. Simmons, Chief

Fuels \& Materials Branch

DRD \& $T$

USAEC

Washington 25, D. C.

Dr. I. Zartman, Chief

Reactor Physics Branch

DRD \& $\mathrm{T}$

USAEC

Washington 25, D. C.

Mr. S. Levine, Chief

Test Power Reactors Safety Branch

Division of Reactor Lisensing

DRD \& $T$

USAEC

Washington 25, D. C.

Mr. D. Pollock, Chief

Adm. , Budget and Program Analys is

Division of Reactor Development and Technology

U. S. Atomic Energy Commission

USAEC

Washington. D. C. 